\title{
XAMANISMO TREMEMBÉ, ABERTURA DE LUGARES E FORMAÇÃO DE PESSOAS INDÍGENAS
}

\author{
Tremembé shamanism, opening places and training indigenous people
}

Chamanismo tremembé, abriendo plazas y formando indígenas

Ronaldo de Queiroz Lima ${ }^{1}$

\begin{abstract}
Resumo:
A minha preocupação é refletir sobre a produção de existência indígena a partir da relacionalidade parental, do xamanismo e da abertura de lugares. Parto das compreensões de parentesco como história (GOW, 1997: 39-65), da reprodução parental como criadora de novos lugares (VIEIRA, 2010:42-91) e do xamanismo como comunicação cósmica (CASTRO 2002, p.457-472) e (2009, p. 101-114), para argumentar sobre como a existência indígena é produzida em termos relacionais entre humanos e não humanos (JACKSON, 2013: 3-28). Para tanto, analiso material etnográfico produzido entre os anos de 2013 e 2015 sobre o trabalho de cura tremembé em Queimadas, no município de Acaraú, estado do Ceará. Considero a cura tremembé uma prática xamânica (MARÉCHAL \& HERMANN 2018: 344) transversal à parentela e a criação de lugares. O não humano aqui se refere aos encantados, espíritos com os quais pessoas tremembés, especialmente de Queimadas, se relacionam como pessoas. A noção de uma existência entre humanos e não, evidenciada pelos dados etnográficos expostos na sequência argumentativa do texto, é a referência da qual parto para sugerir que a abordagem etnológica fixada pela relação entre etnicidade e território sobre os Povos Indígenas no Nordeste do Brasil pode ser revisada.
\end{abstract}

Palavras-chave: Xamanismo; Tremembé; Parentela; Existência.

\begin{abstract}
:
My aim is to reflect on the production of indigenous existence based on parental relationality, shamanism and the opening of new spaces. I start from the understanding of kinship as history (GOW, 1997: 39-65), from parental reproduction as the creator of new places (VIEIRA, 2010: 42-91) and from shamanism as cosmic communication (CASTRO 2002, p.457-472) and (2009, p. 101-114), to argue about how indigenous existence is produced in relational terms between humans and non-humans (JACKSON, 2013: 3-28). Thus, I analyze ethnographic material produced between the years 2013 and 2015 on the tremembé healing work in Queimadas, in the municipality of Acaraú, state of Ceará. I consider tremembé healing to be a shamanic practice (MARÉCHAL \& HERMANN 2018: 344) transversal to the kindred and the creation of places. The non-human here refers to the enchanted, spirits with whom tremembé people, especially from Queimadas, relate as humans. The notion of a plaa plane of existence between
\end{abstract}

\footnotetext{
${ }^{1}$ Doutorando no PPGA/UFBA. Email: ronaldodequeirozlima@gmail.com
} 
humans and not, highlight by the ethnographic data exposed in the argumentative sequence of the text, is the reference from which I start to suggest that the ethnological approach stuck on the relationship between ethnicity and territory on Indigenous Peoples in Northeast Brazil can be revised.

Keywords: Shamanism; Tremembé; Parentela; Existence.

\section{Resumen}

Mi preocupación es reflexionar sobre la producción de la existencia indígena basada en la relacionalidad parental, el chamanismo y la apertura de lugares. Partiendo de la comprensión del parentesco como historia (GOW, 1997: 39-65), la reproducción parental como creadora de nuevos lugares (VIEIRA, 2010: 42-91) y el chamanismo como comunicación cósmica (CASTRO 2002, p.457-472) y (2009, p. 101-114), para discutir sobre cómo se produce la existencia indígena en términos relacionales entre humanos y no humanos (JACKSON, 2013: 3-28). Para ello, analizo material etnográfico producido entre los años 2013 y 2015 sobre el trabajo de sanación tremembé en Queimadas, en el municipio de Acaraú, estado de Ceará. Considero que la sanación tremembé es una práctica chamánica (MARÉCHAL \& HERMANN 2018: 344) transversal a los parientes y la creación de lugares. Lo no humano aquí se refiere a los espíritus encantados con los que las personas que tiemblan, especialmente de Queimadas, se relacionan como personas. La noción de existencia entre humanos y no, evidenciada por los datos etnográficos expuestos en la secuencia argumentativa del texto, es la referencia a partir de la cual comienzo a sugerir que el enfoque etnológico fijado por la relación entre etnia y territorio en los Pueblos Indígenas del Nordeste brasileño puede ser revisado.

Palabras clave: Esencial, Minéria, Estrategia, Pandemia.

\section{Introdução}

Neste artigo demonstro que não é mais possível sustentar que as aldeias indígenas contemporâneas são necessariamente condicionadas a um território do passado colonial. Mas, que as aldeias são lugares indígenas constituídos constantemente pela reprodução parental, em terra de antigo aldeamento missionário e fora desse contexto. No caso analisado aqui, a relação espiritual entre pessoas tremembé e encantados mediou a criação de duas aldeias, Queimadas e Telhas, as quais hoje são protegidas como Terra Indígena. Analiso a relação entre pessoas tremembé e os encantados no trabalho de cura como um ritual xamânico para demonstrar que os encantados não podem mais ser compreendidos como representação simbólica a serviço da relação entre etnicidade e território. Isso porque os encantados têm existência própria, se relacionam com os tremembés e com não indígenas de modo a curar enfermidades do corpo e da alma.

Além disso, essa relação é um canal de comunicação cósmica fundamental para a subsistência de famílias tremembé, para a luta pelo direito territorial e para compartilhar um conhecimento capaz de sustentar um pensamento ameríndio que significa a vida tremembé, bem como um leque de relacionalidades humanas e não humanas.

No primeiro tópico discorro sobre como se deu a minha experiência relacional com os tremembé em Queimadas durante o meu trabalho de campo (CLIFFORD 2002, p.227-251). No segundo, inicio remetendo o etnônimo Tremembé à coadunação entre humano e área pantanosa, os trememdais. Apresento informações sobre o Povo Tremembé no Ceará e faço uso desse termo com iniciais maiúsculas para enfatizar o sujeito político e de direito. Uso constantemente o termo pessoa tremembé em minúsculo para enfatizar que a natureza humana é constantemente formada pela convivência na rede parental. 
Uso o termo pessoa para os encantados. Esses últimos são espíritos e força cósmica de cura, na perspectiva tremembé. Tal uso se dá com menor frequência e enfatiza a dimensão não humana que é encorpada - no sentido dado por Castro (2002, p.457-472) - no corpo de pessoas tremembé iniciadas no trabalho de cura. Uso também o termo tremembés no plural para me referir ao sujeito político e de direito como constituído por experiências vividas - no sentido de Ingold (2015, p.215-229) - que são diversas. Em termos de existência, os tremembé são vários, em termos de sujeitos políticos e de direito, de cidadania, são um Povo Indígena no Nordeste. Ainda no segundo tópico, apresento dados populacionais, informações sobre a localização dos tremembés e as suas respectivas aldeias, sobre a situação territorial de cada uma delas, sobre o contexto social no qual estão inseridas.

No tópico três trato de diferenciar Terra Indígena e aldeia indígena a partir da função social desempenhada pela relação entre pessoas tremembé e encantados na constituição da Terra Indígena Tremembé de Queimadas. O parentesco tremembé é tratado como história (GOW, 1997: 39-65) e a abertura do lugar indígena Queimadas como consequência da expansão parental tremembé (VIEIRA, 2010: 42-91) para o Baixo Acaraú. As relações parentais que fundamentam o argumento aqui desenvolvido são representadas na imagem a seguir.

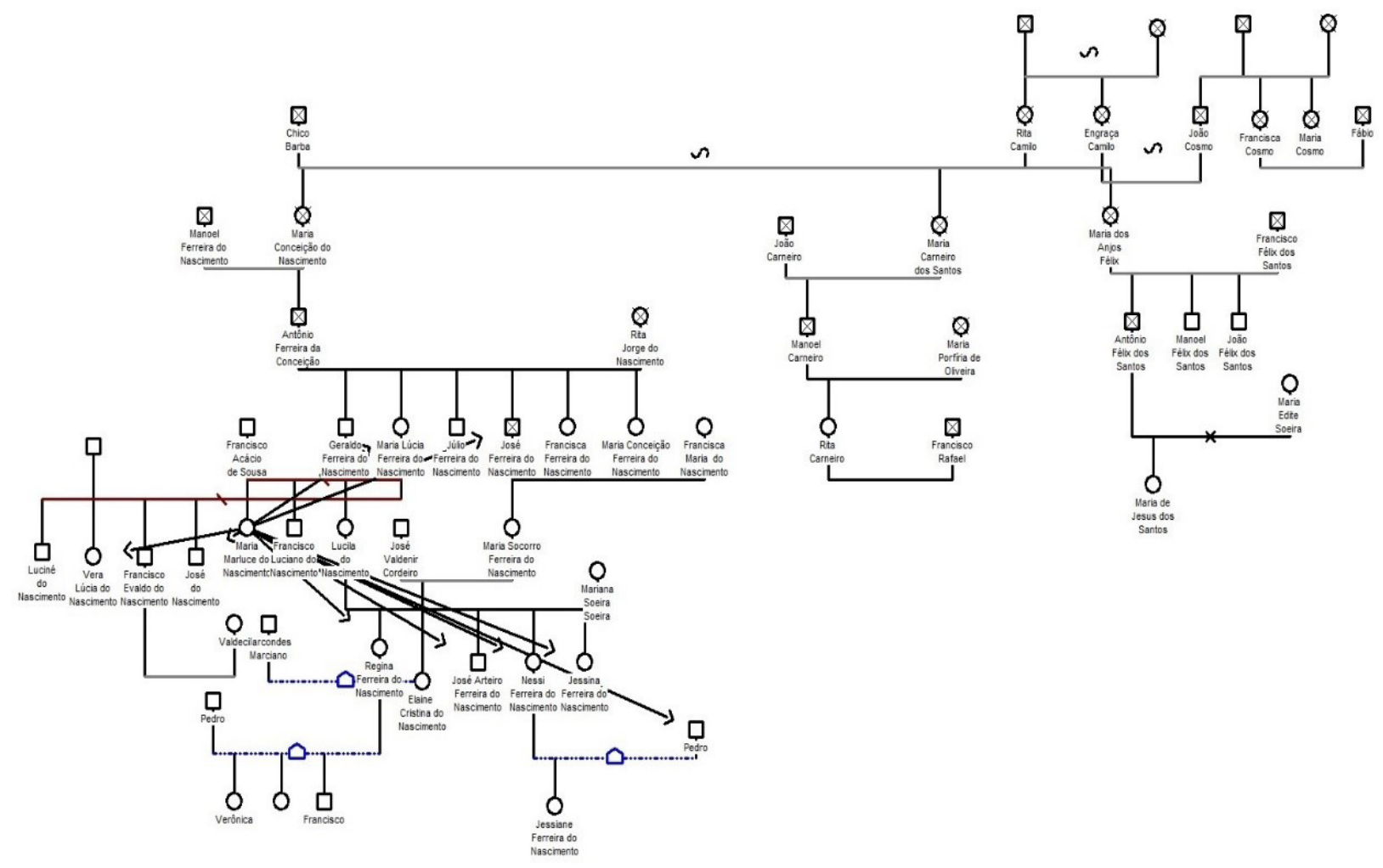

Figura 1 - Matrilinearidade. Fonte: Lopes (2014) e Lima (2015).

Ainda no terceiro tópico, apresento também dados sobre o contexto social que constitui Queimadas. Do mesmo modo, conduzo a narrativa para demonstrar que a aldeia Queimadas está vinculada a outros lugares, indígenas e não indígenas, por diversas relacionalidades comerciais e de parentesco. É o parentesco tremembé que vincula Queimadas a Almofala e fundamenta-a como aldeia Tremembé, o que a tornou sujeito social de direito constitucional, a partir da Constituição Cidadã. Tal vínculo não torna Queimadas um apêndice de Almofala, mas é algo que constitui a história desse lugar indígena.

No quarto tópico apresento argumento no sentido de que os encantados não podem ser compreendidos ou tratados como representação simbólica a serviço da exposição do contraste interétnico, cujo obje- 
tivo seja a garantia de direitos. A perspectiva tremembé apresentada aqui demonstra que os encantados são pessoas não humanas com as quais as pessoas tremembé se relacionam ao ponto da fundação de aldeias ser implicada por essa relação, tanto quanto o processo de demacarção da Terra Indígena de Queimadas. Isso revela um limite da abordagem elaborada pelos estudos de contato e da compreensão sobre a agência de grupos indígenas em favor dos seus direitos constitucionais e na relação com o Estado. Relacionalidades entre humanos e não humanos significam os "traços diacríticos" (CUNHA 1978, p. 237) expostos para a sociedade nacional, mas tomá-los como a representação da cultura indígena é se contentar com a dimensão discursiva do fato étnico. Diante disso, sugiro deslocamento na região de pensamento (DELEUZE \& GUATARRI, 1991) etnológico para dentro do grupo e passo a desenvolver narrativa sobre a formação da aldeia Queimadas.

No quinto tópico discorro sobre o trabalho de cura em Queimadas, de modo a propor compreender essa dinâmica ritual como um xamanismo. Para tanto, sobre xamanismo, parto da proposição de Eduardo Viveiros de Castro (2002, p. 457-472) e de Carneiro da Cunha (2009, p. 101-114) com fim de revisitar o trabalho de cura tremembé em Queimadas. Para o primeiro, o xamanismo é uma capacidade de certos humanos de transpor o corpo e assumir a perspectiva de subjetividades não-humanas. Todas as espécies pensam, são dotadas de intencionalidade e povoam o cosmo. O xamã faz a interlocução entre as diferentes espécies do cosmo de modo a operar as categorias de pensamento imanadas em diferentes contextos socionaturais. Para a segunda, o xamanismo se dá na equivalência de códigos de linguagem cósmica fundada na percepção do xamã, que é um viajante do tempo e do espaço, ao mesmo tempo, é um tradutor de diferentes visões. Contexto de prática xamânica (MARÉCHAL \& HERMANN 2018, p. 344).

No sexto e último tópico, retomo a ideia inicial sobre a formação de aldeias indígenas em terras de aldeamento missionário e fora delas, o que revela uma limitação do modelo etnológico fixado na relação entre etnicidade e território. Não faço uma crítica a esse modelo aqui, embora compreenda que ela seja necessária com base na etnografia nordestina. Tal crítica não implica em diluir o argumento de sustentação do direito originário, ao contrário, trata-se de revisá-lo de modo a expor evidências etnográficas que demonstram o porquê da posse indígena das terras onde habitam deve ser compreendida como um direito humano irremediável, tanto quanto o direito à vida o é. Apresento a aldeia como um organismo vivo. Tal como um corpo humano, no sentido de ser gerado constantemente, no ambiente físico, social e cósmico. Essa forma de vida humana está sob constante ameaça, ao passo que as terras indígenas nordestinas demoram bastante para serem demarcadas. É necessário aprofundar o sentido de ser indígena e com ele a diversidade da existência humana.

\section{Da experiência etnográfica em Queimadas}

O objetivo deste tópico é expor algumas informações sobre como se deu a minha convivência com as pessoas tremembé em Queimadas e como foi sendo construído os dados etnográficos mobilizados no decorrer do texto.

Evaldo, irmão de Marluce, a pajé do trabalho de cura, a liderança espiritual, me convidou para ficar hospedado em Queimadas, após a minha segunda visita à aldeia. Sempre dormi na sala de estar da casa da Marluce. Fazia refeições na sala de jantar, sempre mantive o hábito de lavar a louça. Vez ou outra, dormi e fiz refeições na casa da dona Lúcia, mãe de Evaldo e Marluce. Na maioria das vezes sozinho, como costumo viajar para trabalho de campo, levava os equipamentos de foto e filmagem para as sessões do trabalho. A cada viagem, eu entregava fotos impressas e vídeos em DVD para Marluce. Esse material foi sendo circulado entre as pessoas do núcleo doméstico da pajé e entre as médiuns e seus respectivos núcleos.

Ver as fotos e assistir aos vídeos funcionou para mim como apoio para compreender o processo ritual do trabalho de cura, saber o nome das pessoas e do parentesco entre elas. Para os tremembé, tanto desempenhou 
a função de valorizar o trabalho de cura diante de núcleos domésticos distantes, como a de preparar a iniciação. Tornou-se, o material audiovisual instrumento pedagógico de ensino e de sensibilização da parte dos parentes que não legitimavam o trabalho. A observação, a filmagem do ritual e o registro fotográfico eventual se davam à noite. Somente nesse turno é possível abrir mesa, ou seja, realizar o trabalho. As explicações das chefes do ritual, Regina, Lúcia e Marluce eu sempre obtinha durante o dia. Geralmente, após o almoço, eu conversava com Regina no terreiro de sua casa. Pela manhã, conversava com Marluce ou com dona Lúcia.

Após assistir, filmar, fotografar e tomar nota em mais de trinta sessões e de acumular horas de conversa com Regina, e as outras duas chefes do ritual, como também com outras pessoas auxiliares do ritual da cura, foi possível começar a compreender a linguagem do trabalho.

Compreendi (LIMA, 2015, p. 147-157) que o trabalho de cura dos Tremembé de Queimadas é uma prática mantida, ao longo do tempo, por diferentes gerações de pajés, cujas experiências foram enriquecendo essa tradição com elementos culturais diversos. Por outro lado, revisito aqui parte do material etnográfico produzido nessa experiência com o propósito de refletir sobre como os Tremembé produzem as suas condições de existência.

Nesse sentido, tomo como referência a noção da reprodução parental como consequência a abertura de aldeias (VIEIRA, 2010, p. 42-91), seja pela expansão do núcleo doméstico ou pela aliança uxorilocal. Tomo o parentesco enquanto relacionalidades parental, cognática e agnática, como história (GOW, 1997, p. 39-65) para mobilizar as narrativas tremembé sobre a abertura de seu lugar Queimadas e sobre os lugares-encantados.

\section{O Povo Tremembé no Ceará}

O etnônimo Tremembé condensa a experiência humana vivida em terrenos úmidos na faixa litorânea do nordeste brasileiro ${ }^{2}$. Há uma população consciente da identidade tremembé no Ceará que somava 4.820 pessoas, em 2009, e estão distribuídas entre os municípios de Acaraú, Itapipoca e Itarema (AIRES; SILVA, 2009, p. 9). As localidades onde habitam são denominadas aldeias e o lugar de referência ancestral é a antiga terra do aldeamento missionário fundado em Almofala no século XVIII. Hoje, é distrito do município de Itarema. Os tremembé nomeiam suas aldeias constituídas a partir da missão setecentista como: Batedeira, Batedeira II, Cajazeiras, Capim Açu, Comondongo, Curral do Peixe, Lameirão, Mangue Alto, Panan, Passagem Rasa, Praia de Almofala, São José, Saquinho, Tapera, Urubu, Varjota (PALITOT, 2009, p. 42). Há também fora da terra do aldeamento as seguintes aldeias: Telhas e Queimadas, no município de Acaraú, São José e Capim Açú, no município de Itarema, e São José e Buriti, no município de Itapipoca.

As aldeias Telhas, Queimadas, São José, Capim Açú, São José e Buriti resultam da migração de famílias do antigo aldeamento. O crescimento populacional tornou as poucas áreas de plantio, de caça e de pesca menores, no litoral. Segundo os estudos etnográficos disponíveis ${ }^{3}$, desde o século XIX a microrregião denominada Baixo Acaraú, a planície úmida do segundo maior rio cearense, é habitada por tremembés. As famílias formadas a partir desse movimento migratório, em direção ao Baixo Acaraú, deram origem as aldeias de Telhas, Queimadas, São José e Capim Acú, as quais se tornaram objeto de proteção e administração do Estado Nacional, no início do século XXI. Cada uma das referidas aldeias é uma unidade

\footnotetext{
2 O Etnólogo Tomaz Pompeu Sobrinho (1951) com base nas crônicas seicentistas dos missionários Padre Ivo d’Evreux, capuchino francês, e do jesuíta João Filipe Beteford, afirma que "Habitavam os Tremembé as práias e estuários cobertos de mangues dos rios do nordeste do Brasil, desde a foz do rio Gurupí até a foz do rio Apodí, isto é, toda a costa dos atuais Estados do Maranhão, Piauí e Ceará." (POMPEU SOBRINHO 1951, p.258).

${ }^{3}$ Silva (1999), Patrício (2010) - esses dois laudos antropológicos fundamentados em estudos etnográficos densos são fontes etnohistóricas importantes sobre a ocupação tremembé fora de Almofala -, Lopes (2014) e Lima (2015).
} 
organizativa autônoma conectada as demais pela rede parental. Resulta da experiência vivida e compartilhada pelas pessoas tremembé, ao longo da formação do Estado Nacional, no caso de Almofala, e noutra temporalidade no caso das aldeias formadas fora da terra do aldeamento.

Entre os anos de 2013 e 2015 , desenvolvi pesquisa etnográfica e dissertação $0^{5}$ com pessoas tremembé na Terra Indígena (TI) Tremembé de Queimadas, no município de Acaraú, no Ceará. Embora a regularização fundiária não tivesse terminado, esse grupo indígena gozava do direito territorial à posse permanente de seu território. Essa TI foi criada no ano de $2010^{6}$. Ela está a 34 quilômetros da sede municipal, a qual dista 237 quilômetros da capital Fortaleza. A TI Tremembé de Queimadas é limítrofe à TI Tremembé Córrego do João Pereira ${ }^{7}$, cujo perímetro tanto está no município de Acaraú como no de Itarema. As pessoas tremembé que vivem nas aldeias São José e Buriti também detêm a posse permanente ${ }^{8}$ do território conformado na TI Tremembé Barra do Mundaú, no município de Itapipoca, a 120 quilômetros de Almofala.

O processo de demarcação da TI Tremembé de Almofala parou em 1992 e aguarda decisão judicial para finalização dos estudos. A terra do aldeamento é compreendida pelos tremembé como sendo dividida em duas áreas menores, as quais são denominadas de mata e praia. Almofala, hoje, é uma das praias do município de Itarema e um dos principais destinos de banhistas nos finais de semana e feriados. Abriga vários não indígenas que são chamados de posseiros e a atividade da pesca e da agricultura de roça são as principais atividades tradicionais de subsistência. Não há mais mata para a caça em função da degradação ambiental promovida por fazenda de coco.

A porção norte do Ceará, litoral oeste onde estão localizadas as TIs Tremembé de Almofala e da Barra do Mundaú, é rota turística para Jericoacoara e outros destinos turísticos em ascensão. Essa faixa litorânea é referência mundial para a prática do kitesurf ${ }^{9}$ e constitui a principal matriz brasileira de geração de energia eólica ${ }^{10}$. O investimento em usinas eólicas no Ceará é um dos vetores da transformação socioambiental do litoral cearense ${ }^{11}$, nas últimas décadas. Essa região física e biótica também têm atraído empreendedores do setor hoteleiro e empresários do setor agrícola. A política econômica estadual tem fa-

\begin{abstract}
${ }^{4}$ Esse foi o período em que fiz o curso de mestrado em Sociologia no Programa de Pós-Graduação em Sociologia (PPGS) da Universidade Federal do Ceará (UFC).

${ }^{5}$ O título da dissertação é: Os Tremembé do Centro de Cura, em Queimadas: a formação de um grupo social, (LIMA 2015). Esse trabalho foi desenvolvido a partir das ideias de "situação histórica" (OLIVEIRA FILHO, 1988) e "Territorialização" (OLIVEIRA FILHO, 1999). O objetivo central foi demonstrar que o grupo social de curadoras e curadores tremembé de Queimadas foi formado no "processo de territorialização" dessa aldeia. Nesse momento, os indígenas puderam retornar para a área de onde saíram devido a posse do Departamento de Obras Contra a Seca (DNOCS) com o fim de lotear a terra e esquadrinhá-la para o grande projeto do Perímetro Irrigado Baixo Acaraú.

${ }^{6}$ O Relatório Circunstanciado de Identificação e Delimitação (RCID) da Terra Indígena Tremembé de Queimadas foi escrito no ano de 2010 pela antropóloga Marlinda Melo Patrício (PATRíCIO 2010), contratada pela Fundação Nacional do Índio (FUNAI). O resumo do RCID foi publicado no Diário Oficial da União em 30 de dezembro de 2011 (BRASIL 2011). Desde então, as pessoas tremembé que vivem na TI de Queimadas detém a posse permanente desse território de 767 hectares.
\end{abstract}

7 Única TI homologada no Estado do Ceará. A regularização fundiária terminou em 2003 (BRASIL 2015).

${ }^{8}$ Portaria número 1.318, de 7 de agosto de 2015. Disponível em: https://pesquisa.in.gov.br/imprensa/jsp/visualiza/ index.jsp?jornal=1\&pagina=33\&data=11/08/2015. Acessado em 06 de outubro de 2020.

${ }^{9}$ Ver https://www.ceara.gov.br/2019/09/24/ceara-e-referencia-mundial-para-praticantes-dos-esportes-nauticos/. Acessado em 5 de outubro de 2020.

${ }^{10}$ Ver https://clickpetroleoegas.com.br. Acessado em 5 de outubro de 2020.

${ }^{11}$ Os parque eólicos estão nos seguintes municípios: "Icapuí, Aracati, Beberibe, Cascavel e Aquiraz (litoral leste); Caucaia, São Gonçalo do Amarante, Paracuru, Paraipaba, Trairi, Amontada, Acaraú, Cruz, Jijoca de Jericoacoara, Camocim e Barroquinha (litoral oeste)" (MOURA-FÉ 7 PINHEIRO 2013, p.25). 
vorecido ambos os setores, nos últimos anos. Todas as TIs Tremembé citadas sofreram e sofrem impactos de empreendimentos do ramo hoteleiro, agrícola, de geração e distribuição de energia "limpa".

Visitei as já referidas aldeias entre os anos de 2016 e 2017. Observei que as atividades produtivas de maior movimentação de pessoas tremembé e dessas com não indígenas são: a pesca artesanal e industrial, a agricultura familiar, a monocultura de agroempresas; o serviço de transporte e o bancário; o comércio de frutos do mar, de horticulturas, de alimentos e a troca deles entre parentes; a venda de animais para consumo e criação; o comércio de eletrodomésticos, de móveis, de roupas e calçados, de veículos motorizados de pequeno porte; os benefícios previdenciários, os benefícios dos programas sociais para pessoas e famílias de baixa renda; a renda proveniente do serviço público diferenciado na área da saúde e da educação em TIs.

Embora o português regionalizado seja o idioma estruturado na fala dessa população indígena, a língua ancestral continua sendo praticada nos cantos do torém. Essa é a dança tradicional tremembé realizada em diversas festividades e atos políticos, cujos significados funcionam como sinais diacríticos desse grupo (OLIVEIRA JÚNIOR, 1998, p. 27, 35-51). O torém é também um ritual indígena, como o toré, a jurema e o ouricuri, praticados por outros povos indígenas na Região Nordeste. As ritualidades indígenas nordestinas - torém, toré, jurema e Ouricuri - reúnem múltiplas crenças espirituais e se aproximam das vivências em Umbanda e no catolicismo popular (MESSEDER, 2012, p. 32-42).

Há uma ritualidade denominada por pessoas tremembé como trabalho de cura ou trabalho. Essa prática ritual de incorporação de encantados não aparece nas mobilizações étnicas. Em Queimadas, pude conversar e conviver com as mulheres que chefiavam o trabalho, Marluce, Regina e Dona Lúcia, mãe da primeira e tia da segunda. A experiência delas e a minha observação disciplinada das sessões de cura, aos poucos, foram me revelando evidências de um sistema simbólico próprio incrementado por significantes de Umbanda e do catolicismo popular. O trabalho de cura que era compreendido como "atualização da tradição cultural dos Tremembé em curar pessoas índias e não índias” (LIMA 2015, p. 183) aqui passa a ser enfatizado a partir da relacionalidade humana e não humana mantida por pessoas tremembés.

\section{Queimadas, Terra Indígena e aldeia}

A relacionalidade entre pessoas tremembés e encantados não se restringe ao âmbito do trabalho de cura. Ela é definidora de Queimadas como uma aldeia ou lugar indígena. Dar atenção à relação entre tremembés e encantados é enfatizar a perspectiva indígena sobre a sua existência. Desse modo, é possível evidenciar um processo constante de elaboração da existência tremembé mediada por encantados. O que não está separado do processo de mobilização étnica para criar uma Terra Indígena nessa localidade. A proteção do Estado Nacional sobre a terra ocupada pelos tremembé favorece a continuidade histórica dessas pessoas indígenas, à medida que possibilita a manutenção do ambiente no qual habitam os encantados.

A TI Tremembé de Queimadas foi identificada e delimitada em parte do terreno loteada pelo projeto Perímetro Irrigado Baixo Acaraú, iniciado no governo Sarney ${ }^{12}$. A construção dessa obra gerou a migração gradativa de várias famílias entre as décadas de 1980, 1990 e 2000. A agência da Procuradoria Geral da República no Ceará (PR/CE), do Ministério Público Federal (MPF), com base em parecer de $2005^{13}$, foi importante por intervir pela desapropriação de parte da terra do Perímetro para as famílias que permaneceram no que restou da formação territorial de Queimadas. O estudo do Grupo Técnico (GT) da FUNAI, em 2010, conseguiu incluir no perímetro da TI Tremembé de Queimadas a Mata do Amargoso por consequência da ação do MPF.

\footnotetext{
${ }^{12}$ Cf. Patrício (2010), Lima (2015).

${ }^{13}$ Parecer Técnico no 1/05. Ministério Público Federal. Procuradoria da República no Ceará (BRISSAC \& MARQUES 2005).
} 
A partir da experiência das pessoas tremembé, trata-se de uma área que foi completamente degrada pela terraplanagem do loteamento, mas que abriga uma lagoa encantada. Segundo a perspectiva tremembé, nesse local habitam encantados, espíritos com quem indígenas iniciados no trabalho de cura se relacionam. O lugar é encantado e isso implica na agência de forças espirituais/naturais que impedem a lagoa de ser vista e a sua água de ser utilizada. Significa também que seria possível desenvolver um trabalho para desencantar a lagoa e fazer a água emergir no meio da mata, exatamente, onde há uma interrupção na paisagem densa da vegetação de tabuleiro por uma espécie de capim ${ }^{14}$. A Mata do Amargoso é encantada por ter uma lagoa sob agência de encantamentos, sete ao todo.

Em caminhadas pela referida Mata com o atencioso Evaldo (irmão de Marluce), pude aprender sobre rastros de animais de valor para a caça, como o peba, o tejo, a juriti e sobre a Caipora. Na entrada da mata, fora das áreas de residência e de cultivo, pôr fumo em algum galho é uma atitude cortês com a encantada. Simboliza um pedido de proteção a ela contra quaisquer ataques dos animais e de espíritos que lá vivem.

Após cada caminhada na Mata, uma lógica de andar por dentro da vegetação foi se apresentando e o indígena me mostrando como a vida nesse ecossistema não era mais a mesma. Depois das obras do Perímetro Irrigado, tanto o veado, como a cutia, o preá e o catitu não foram mais vistas nas proximidades. Luciano, irmão de Evaldo e reconhecido caçador em Queimadas, me disse que o loteamento ${ }^{15}$ da terra afugentou os animais. Outro impacto é gerado pelo uso de agrotóxicos nos cultivos dos lotes. A substância contamina o solo e a água em uso pelas pessoas tremembé e pelos animais que ainda vivem na Mata, como o peba.

No entanto, a experiência de Evaldo, Luciano e de outros caçadores de Queimadas informa que o encantado Caipora permanece agindo de modo a proibir ou consentir a apreensão de animais pelos caçadores. O que tiver a marca da Caipora no corpo não deve ser consumido pelos humanos por pertencer ao encantado. Segundo a perspectiva tremembé, casos em que caçadores não conseguiram capturar as suas presas é compreensível porque os animais alvejados pertenciam a Caipora. Além disso, tomar uma surra da Caipora é uma punição dada a humanos e não humanos, cachorros, que entram na Mata em busca dos animais que não lhes pertencem ou para coletar lenha e frutos silvestres sem ter ofertado o fumo. O pedido de permissão à Caipora também pode ser feito no trabalho em ambiente reservado para isso ${ }^{16}$.

A cadeia de impactos promovida pela construção e operação dos loteamento do DNOCS provocou alterações no ecossistema da região do baixo Acaraú. Elas permanecerão impactando a vida das pessoas tremembé de Queimadas e dos animais que vivem na Mata do Amargoso. Queimadas é cercada por loteamentos do Perímetro Irrigado. Por outro lado, a lagoa permanece encantada no meio da Mata, e os tremembé se relacionando com os encantados.

A estrutura de vida em Queimadas foi sendo complexificada, precisamente, após ação do MPF em 2005, mencionada anteriormente. As famílias que saíram de Queimadas para tentar sobreviver à fome, porque não podiam plantar na terra apossada pelo DNOCS, retornaram, gradativamente, após saberem da posse dos parentes que haviam ficado. Esse movimento gerou mudança no número de famílias de 12 para 67, um aumento de aproximadamente 200 pessoas entre 2005 e 2014 (LIMA 2015, p. 67). Até esse momento, as pessoas em Queimadas recebiam visitas semanais de enfermeira e de agentes indígenas de saúde e saneamento.

\footnotetext{
${ }^{14}$ Cf. Lima (2015, p. 34).

${ }^{15}$ Lotear trata-se de suprimir toda a vegetação, incluindo as raízes das árvores maiores, de revirar o solo e dividi-lo em quadriláteros iguais. E isso aconteceu com o uso de maquinário pesado ao longo das décadas de 1980, 1990 e 2000. Esse foi o período de duração das obras do Perímetro que tem mais de 40 mil hectares de extensão ao longo dos municípios de Acaraú, Cruz e Marco (LIMA 2015, p.65 apud PATRíCIO 2010).

${ }^{16}$ Apresento adiante o Centro de Cura
} 
A Escola Indígena Tremembé de Queimadas tanto dá emprego aos indígenas qualificados para os cargos de professor, diretor, secretário, merendeira, como atende crianças e adultos em diferentes níveis de ensino.

A TI está organizada no Conselho dos Índios Tremembé de Queimadas, cuja representatividade corresponde às "três famílias extensas" Custuosos, Félix e Carneiro (LOPES 2014, p. 39). A distribuição espacial das residências reproduz a classificação parental nos três entroncamentos genealógicos citados. Entretanto, a geração de consanguinidade a partir do casamento de pessoas dessas diferentes famílias constitui Queimadas como uma aldeia, uma família só cujos corpos tremembés estão vinculas por ligação agnática. A elaboração da parentela iniciada no casamento se expande para o nascimento de crianças, quando o compadrio é estabelecido. A reciprocidade do matrimônio, para além do vínculo biológico, desencadeia tanto o processo de geração de pessoas tremembé como o de inclusão de outras não indígenas. Esse movimento conforma um sistema social para dentro e para fora de Queimadas de modo a constituir a história da aldeia imersa nas dinâmicas regionais do Baixo Acaraú.

Em Queimadas, se vive da agricultura familiar de subsistência. As pessoas cultivam roça e algumas leguminosas. Vendem castanhas apanhadas na mata disponível, durante o segundo semestre, e assam um tanto para comer. Complementam a dieta com galinha, porco, alguma caça e, rara a vez, com peixe. Boa parte dos núcleos familiares Félix, Carneiro e Custuoso têm pessoas aposentadas, empregadas nos lotes ou que são servidoras da Saúde ou da Educação Indígena. Todo início de mês, quem têm salário ou algum benefício previdenciário a receber viaja para a sede do município de Acaraú em carros do tipo pau de arara. Saem de casa ainda à noite e retornam por volta do meio dia. Esse fluxo é comum na microrregião do baixo Acaraú. As contas mensais são de água, de luz e de telefone. A água e a energia elétrica foram conseguidas enquanto medidas de compensação do DNOCS, e a telefonia móvel funciona mediante a compra de créditos.

Além disso, os gastos pessoais se dão com alimentos, roupas, utensílios domésticos e material de construção para melhorar as casas feitas de alvenaria. Para os que possuem moto e ferramentas de trabalho para a agricultura, ou para a caça, sempre há pequenos gastos de manutenção. Queimadas é via de passagem para outras localidades, tais como Lagoa do Carneiro, Cajueiro do Boi, Pedrinhas, Volta, Córrego do João Pereira e Lagoa dos Negros. As atividades produtivas e o acesso a programas sociais e benefícios da previdência são vivências comuns à população não indígena e indígena dessa parte do Baixo Acaraú.

Com o passar do tempo, fui percebendo que em todos esses lugares haviam pessoas com quem os tremembés, tanto de Queimadas como de Telhas, mantinham relacionalidades comerciais e de parentesco. A parentalidade tremembé elaborada fora do aldeamento de Almofala, antes da ação da política indigenista estatal disciplinada a partir de 1988, fundamenta a proteção de Queimadas como uma Terra Indígena pelo Estado Nacional. Esse lugar indígena é uma aldeia constituída de modo espontâneo pelas famílias de migrantes, não é um aldeamento, o que é criado por uma política de Estado. Embora esse grupo tenha migrado de Almofala e apresente expressões culturais como os seus parentes do litoral, tais como o Reiso (LIMA 2011), o torém (OLIVEIRA JÚNIOR 1998; LOPES 2014) e o trabalho de cura (GONDIM 2010; LIMA 2015), o que sugere uma diáspora ${ }^{17}$, ele é de Queimadas, não de Almofala. Isso significa que o sentimento de pertencimento étnico de Queimadas ao povo tremembé constituído na terra do aldeamento setecentista se mantém mesmo fora da área de colonização antiga. Isso implica compreender o parentesco e seus deslocamentos como centrais no fenômeno étnico.

Além disso, fui percebendo também que o trabalho de cura é uma relacionalidade a qual vincula pessoas tremembé e todas as outras circunvizinhas. A prática ritual no trabalho de cura faz circular re-

\footnotetext{
${ }^{17}$ No sentido dado por Stuart Hall (2013, p. 27-55) sobre a ressignificação de referentes culturais do lugar de origem noutras terras, do sentido de pertencimento e da identidade diaspórica.
} 
ferentes e significados produzidos entre as tremembé curadoras e os encantados. Há uma linguagem da cura que media as relações de parentesco, para dentro de Queimadas e para fora da aldeia. Na dimensão interna é que se dá a relacionalidade com os espíritos no trabalho, no âmago do parentesco. A parentela e o trabalho se referem a relacionalidades entre humanos e não humanos as quais se aproximam da ideia de xamanismo (CUNHA 1998, CASTRO 2002).

\section{Pessoas tremembé, encantados e xamanismo}

Os rituais indígenas do torém e do toré são os mais conhecidos, entre os povos indígenas nordestinos, por consequência da agência política em operar contraste cultural (CUNHA 1978, p. 258) diante da sociedade nacional. Ganham novos significados no contexto de luta política pela demarcação de territórios tradicionais. Por isso são os mais conhecidos. Nesse sentido, os encantados têm atenção da Antropologia Histórica ${ }^{18}$ enquanto significantes da linguagem da etnicidade, a qual é operativa da diferença no contexto de disputa interétnica por territórios tradicionais, ao longo da formação histórica do Estado Nacional ${ }^{19}$. Essa compreensão vem influenciando os estudos sobre povos indígenas nordestinos nos últimos vinte anos. Nessa região etnológica, o território permanece mediando a relação entre a pessoa e o grupo étnico (OLIVEIRA FILHO 1999, p. 31).

Porém, para os tremembé de Queimadas, os encantados têm existência própria (LIMA, 2015, p. 21) tanto quanto os humanos. Essa evidência implica em pensar esses espíritos como sujeitos relacionais no contexto de vida de pessoas tremembé. Isso direciona para outra região de pensamento (DELEUZE \& GUATARRI, 1991) etnológico.

A abordagem fenomenológica sobre a relação entre tremembé e encantados é recente. Para a antropóloga Juliana Gondim, a consequência da relação entre humanos e não humanos é uma multiplicidade de mundos, cuja agência dos encantados se manifesta em ocasião de cura, em eventos políticos e nos encontros com humanos na "natureza" (GONDIM, 2016, p. 28-71). Para a antropóloga Janaína Fernandes, escrever a terra a partir da percepção das pessoas tremembé possibilita compreendê-las como parte da primeira, para além da ideia de território ${ }^{20}$ (FERNANDES, 2015, p. 16-38). Nesse sentido, os encantados passam a ser tomados como experiências vividas "um acontecimento ou um objeto só podem ser avaliados como encantes depois de terem sido vivenciados" (FERNANDES, 2019, p. 48).

Esses estudos demonstram uma abordagem fenomenológica e simétrica sobre as experiências tremembé em Almofala e sugerem um deslocamento heurístico dos encantados como representação simbólica para pessoas não humanas, a partir da experiência tremembé. As antropólogas auxiliam a pensar sobre

\footnotetext{
${ }^{18}$ Eu me refiro à coletânea "A viagem da volta: etnicidade, política e reelaboração cultural no Nordeste indígena", organizada, apresentada e iniciada pelo professor do Programa de Pós-Graduação em Antropologia Social do Museu Nacional, Universidade Federal do Rio de Janeiro, doutor João Pacheco de Oliveira Filho. O organizador ofertou ao público oito artigos escritos por diferentes antropólogos que apresentaram evidências etnográficas sobre o pertencimento étnico de indígenas ser mediado pelo território objeto de luta para ser demarcado, em diferentes contextos históricos no nordeste. Além disso, essa coletânea exerceu e exerce influência sobre as etnografias produzidas sobre algum povo indígena no Nordeste.

${ }^{19}$ Outras referências de Antropologia Histórica sobre as vilas de índios no Ceará (SILVA, 2005: 73-84) e sobre o argumento crítico à "extinção" dos índios (VALLE, 2009: 107-154), (SILVA, 2011: 327-346) e (VALLE, 2011: 447-482), permanecem sustentando evidências da continuidade histórica dos índios no Ceará ao longo da formação do Estado nacional.

${ }^{20}$ Nas sessões anteriores expus informações sobre a garantia do direito territorial de diferentes grupos tremembé a partir de Terras Indígenas delimitadas em diferentes municípios do Litoral Oeste do Ceará. Este artigo não trata desse tema, tão pouco de questionar os fundamentos antropológicos da territorialidade. Pretende-se aqui colaborar com a reflexão etnológica a partir da percepção tremembé sobre a relacionalidade humana e não humana estabelecida com encantados, tanto nos territórios tradicionais como para além deles.
} 
a relacionalidade humana e não humana que perfaz uma ontologia relacional tremembé, seja com mitos, seja com a experiência em encontros com encantados em diferentes momentos do cotidiano, na terra do aldeamento. Os dados etnográficos produzidos por mim e por pessoas tremembé, entre os anos de 2013 e 2015, sobre o trabalho de cura em Queimadas também sugerem uma ontologia relacional, fora de Almofala. Além disso, a perspectiva tremembé sobre o trabalho sugere que a parentela é importante para a comunicação e encorporação xamânica (CUNHA 1998, CASTRO 2002) dos encantados. A comunicação entre encantados e pessoas tremembé é fundamental para o pensamento ameríndio nesse contexto etnográfico.

Então, após apresentar o contexto no qual os tremembé estão inseridos, a limitação do modelo teórico metodológico dos estudos de contato diante do que a perspectiva tremembé coloca sobre os encantados - pessoas como os humanos - passo à atenção para o trabalho de cura em Queimadas.

Para as pessoas tremembé, a agência dos espíritos se dá tanto sobre os corpos enfermos como sobre o ambiente, é o caso da lagoa encantada e da Caipora na Mata do Amargoso. A mediação dessa agência espiritual é feita por pessoas tremembé cujos corpos e pensamentos foram desenvolvidos para encorporar os encantados. Não se trata de uma transmutação interespécie, mas de corporificar o encantado. O corpo da pessoa tremembé iniciada no trabalho, seja ela com poder de cura (a pajé) ou não (as médiuns), é esvaziado da alma original para recepcionar o encantado. Assim, a performance ritual, dança e canto, a condução dos ritos e a comunicação dos saberes curativos são desempenhados por uma corporalidade híbrida, corpo de um e espírito de outro. Enquanto o corpo é gerado na rede parental e segundo a lógica e a trajetória histórica da aldeia de Queimadas, o espírito tem existência cósmica.

A função central nessa ritualidade é a de pajé21. Trata-se de uma pessoa cujo corpo e alma foram moldados no ritual para curar. É quem foi desenvolvido para receber as correntes de cura, a capacidade de corporificar o conjunto de encantados dotados de saberes curativos. Nesse contexto etnográfico, o pajé é alguém feito para mediar a relação entre os vivos de carne e osso e os encantados, espíritos, no trabalho.

A migração das famílias de Almofala para o Baixo Acaraú foi liderada por pajés e mediada pelos encantados. A constituição dos lugares indígenas nessa microrregião só foi possível por causa da agência espiritual. Em si, o trabalho não consolida lugares indígenas, isso depende da expansão gradativa das famílias e das atividades de subsistência que elas mantêm, as quais também são mediadas pelos encantados e pela disposição ambiental.

Desde o século XIX ao início do $\mathrm{XX}^{22}$, diferentes núcleos familiares tremembé migraram de Almofala para o Baixo Acaraú. João Cosmo liderou a migração que fundou as aldeias de Telhas e Queimadas. Ele foi um pajé que incorporava os encantados e, assim, mediava a comunicação dos saberes espirituais. Etnografias do tema (LOPES, 2014, p. 1-188; LIMA, 2015, p. 1-239) ajudam a compreender que o grupo liderado por João Cosmo caminhava durante o dia e à noite os encantados eram consultados sobre a direção por tomar na manhã seguinte. Nesse ritmo, o conjunto de famílias foi fazendo roça até que chegaram numa lagoa onde plantaram, colheram e ficaram. Como ela foi encontrada a partir da comunicação com os encantados, então, essa lagoa foi desencantada, na perspectiva tremembé. A laguna recebeu o nome de Lagoa dos Negros em referência a cor da pele dos seus "descobridores" e se tornou uma aldeia, com o aumento das famílias. Desse lugar os migrantes foram expulsos por um fazendeiro. Em consequência, eles abriram novos lugares (LIMA, 2015, p. 78-134). Um deles é, hoje, a aldeia de Queimadas.

\footnotetext{
${ }^{21}$ Não se trata aqui de "indianidade" (OLIVEIRA FILHO 1988, p.14), a imagem de grupos indígenas criada por operadores do sistema político-jurídico do Estado de proteção a esse segmento da população nacional, identificada no final da década de 1980.
}

${ }^{22}$ Cf. nota 3 . 
O senhor Cecídio, falecido brincador de Reisado e de Torém, me ajudou a compreender como Queimadas surgiu enquanto aldeia tremembé. Conversamos algumas vezes entre 2010 e 2011 (LIMA, 2011: 69-81). Nessa ocasião etnográfica, Cecídio me recebeu em sua casa por duas vezes. Ficávamos sentados na sala de estar de sua casa de taipa (adobe), de piso cru, porta de duas peças, fechada embaixo e aberta em cima. A esposa estava sempre na cozinha. Ela nos trazia, gentilmente, um café, ou um suco. Certa vez, trouxe um almoço, para minha surpresa. Neste ambiente doméstico é que o finado Cecídio foi tecendo sua memória, lembrança por lembrança, construindo uma teia de falas cuja linguagem trazia para mim dificuldades de entendimento. Termos como catitu, carrinho matilê, nomes de lugares e de pessoas eram sempre acompanhados de um pedido de esclarecimento.

Ai ele foi e disse: "olha muié, eu vou atrás de uma morada pra nós". Agarrou um facãozão
que ele tinha trazido da Amazônia desse tamanho e agarrou o carrinho matilê. Calçou e
tocou-se. Fez uma variante, saiu na Volta, no córrego da Volta. Da Volta ele desceu, saiu
na Gameleira. Ele desceu saiu dentro das Pedrinhas, e das Pedrinhas saiu aqui. Quando
chegou aqui era um queimadão só. Meia légua em quadro. Ninguém achava um galho em
rama. Ele botava a cangalha, os cambitos em cima dos animais, mais os três filhos mais
velhos e tocava, saía aqui. Iam buscar rama no córrego das Telhas. Ai ia com os filhos atrás
de rama, começou a fazer um barraco. Madeira tinha demais, tinha madeira preta toda
queimada. Fez um barraco. Ai, ficou e ficou. Quando era perto do inverno, ele disse: "meus
filhos vamos agarrar os animais e vamos atrás de umas palhas. Pegar umas palhas. Trazia
três cargas de palha braba. Ele tinha uma foicezinha. Cortava, trazia, a palha era braba. Ele
morou cinco anos dentro de uma lápia debaixo de uma casa encapada de palha e não gote-
java. E os outros ai pegaram a encostar. Tudo era família. Chico Andorasa era casado com
uma irmã da mamãe. Já o Carneiro, do mesmo jeito. Felix Inácio, que é o pai desses Felix
que tem aí, era também. E aí, tudinho era família. Que quando souberam que ele estava pra
cá, deram fé, começou a chegar uns com um mês, outros com dois e outros com três. Ai
foram morar nas Queimadas. (Senhor Cecídio, entrevista realizada em Queimadas, 2010).

O finado narrou uma história cujo protagonista foi seu pai e que nos auxilia a perceber como Queimadas, e as outras aldeias indígenas, foram feitas por uma família vivendo dentro de uma mata. De rama em rama, de palha em palha e a cada chegada de parentes afins, a família extensa foi reelaborando a paisagem queimada. Os casamentos, os filhos, os primos, a caça são fundantes dessa aldeia constituída por indígenas sobre as cinzas. Foram os vínculos parentais e o envolvimento com o ambiente que constituíram o lugar tremembé cujo nome Queimadas absolveu a experiência humana da sua fundação. A abertura da aldeia desencadeou veredas por dentro das matas, cada uma com a sua história, as quais ligam lugares no trânsito de humanos e de não humanos (animais, espíritos ou encantados). O lugar começa na relacionalidade parental e vai sendo feito à medida que a família extensa cresce e a necessidade para subsistir aumenta. O pajé João Cosmo fez parte dessa abertura, embora tenha ido morar noutro lugar de nome Córrego da Onça.

As veredas produzidas em Queimadas e o trabalho levaram as pessoas tremembé à saber do encantamento da Lagoa do Amargoso. Dona Lúcia, sobrinha de Cecídio me disse que a lagoa encantada está sob sete encantes. A localização dela está na Mata do Amargoso, próximo ao caminho para a antiga casa de farinha do finado João Furtuoso, um vizinho não indígena. Algumas pessoas tremembé, que são médiuns como Lúcia é, ficam perdidas se entrarem nessa mata sem um acompanhante. Mas, não tive referência de algum caso de pessoa perdida, definitivamente. A crença tremembé na perda de lucidez dentro daquela Mata se dá por causa da agência dos espíritos dos índios, dos encantes, sobre as pessoas. A experiência de Ritinha, tia de Lúcia, exemplifica como a existência da lagoa encantada é comprovada. 
Certa vez, quando Ritinha e Francisca, cunhada de Lúcia, caminhavam em direção à fazenda do falecido João Furtuoso, a primeira esteve em contato com os encantados do seguinte modo, me contou Dona Lúcia.

\begin{abstract}
Aí, ela [Ritinha] foi passando com a comadre Francisca e ela escutou a cantiga tão bonita, a doutrina tão bonita entrando pra dentro do mato. E ela [Ritinha] atrás de ir e a Maria que não deixava, a comadre Francisca não deixava. E ela dizia: Francisca é bem aqui. Eu vou e já já eu venho. E a Francisca: comadre se você for, você se encanta. Como de fato, se ela tivesse ido essa tinha se encantado né. Aquela ali é índia verdadeira também. (Dona Lúcia 2014).
\end{abstract}

Nota-se que as duas mulheres são comadres, são também tia e cunhada de Lúcia. Elas estavam indo de Queimadas à propriedade de não indígena trabalhar na produção de farinha e de goma a partir do beneficiamento da mandioca. A Ritinha escutou o canto dos encantados e foi impedida pela comadre de ir ao encontro deles porque, nessas circunstancias, haveria um encantamento, ou seja, a morte do corpo e a libertação do espírito para a dimensão cósmica. A Lagoa do Amargoso funciona como um portal entre os mundos vivenciados pelas pessoas tremembé. Os corpos humanos são testados aí. Aqueles com a capacidade de encorporar os encantados são os mais suscetíveis a se perder na Mata. Não à toa Ritinha estava acompanhada e foi cuidada pela comadre, cuja experiência de vida no trabalho já havia consolidado o conhecimento da possibilidade do encantamento na travessia do Amargoso.

A narrativa de Lúcia revela que a comunicação entre parentes e os espíritos da Mata demonstra uma identidade indígena. Escutar cânticos de encantado só é possível a uma pessoa tremembé que tem predisposição para ser médium, alguém cujo corpo e a mente podem ser produzidos para se comunicar com a dimensão cósmica dos encantados. Na perspectiva tremembé, além de escutar cânticos, ver espíritos, sonhar com eles, desmaiar, tomar um choque ao pegar na mão de um corpo no qual um encantado está corporificado e vivenciar algumas dessas experiências na Mata, são sinais de posse de correntes. Essa predisposição aparentemente natural, como a dos xamãs amazônicos (CASTRO 2002, p.457-472), é dolorosamente desenvolvida no trabalho até que o corpo e a mente de uma pessoa médium estejam prontos para a comunicação com os encantados. Retomo mais adiante.

Encontrar um lugar mediado pelos encantados no corpo de pajé pode ser compreendido como um encantamento e não um desencantamento, como foi o caso da Lagoa dos Negros. A seguir, destaco outra narrativa de Dona Lúcia sobre como a Lagoa do Amargoso foi encontrada pelos seus parentes mais “antigos" e não foi desencantada.

Era o papai Manoel, que era o meu avô, era o meu pai, era o finado João Carneiro, era o finado Severino, era o finado Mané Carneiro. Dois filhos da minha avó era o finado Joãozinho, era o papai, era o tio Nelson, que tudo era os antigo né, que iam caçar. O João Cosmo, o Mané Cosmo. O João Cosmo era o pajé que trabalhava antigamente, antes do Finado Zé [Zé Tonheza]. Foram caçar e não achavam. Quando era de noite ele ia trabalhar [João Cosmo], aí: tá mais raso, tá saindo os encantes, tá em tanto. Que era sete, né!? Ela estava com sete encantes, quando ficou só num, que era pra descobrir no dia que foram caçar: [encantes] vocês vão caçar que hoje vocês acham. Aí eles [os encantes] ensinavam: aonde eles achassem uma pacova, uma folhinha de pacova, que ela tivesse bem verdinha, achassem rastro de pássaro, de marreca. Escutavam marreca cantar, escutavam a Jaçanã cantar, escutavam tudo, né, voando. E o papai Manoel saiu sozinho. Não saiu pra longe, ficou arrodeando pelo meio, né!? Ele fazia o círculo por fora e vinha fechando. Aí ele achou uma folha de pacova grande. E aí quando ele arribou a folha ele disse: ai meu Deus, a folha tão verdinha, parece que tá dentro d'água. E estava mesmo que o talinho dela estava dentro d'água. Aí quando ele arribou a folha, ele viu a água bem 
azulzinha que era um anil. Aí ele disse que deu vontade de beber, mas imaginou nos outros que estavam morto de sede. Aí pronto, ele saiu e foi caçar. Ai parece que era uma coisa que não tinha pra desencantar. Porque se tivesse desencantado não tinha sobrado para a gente, tinha sobrado pra eles [não indígenas]. (Dona Lúcia 2014).

O avô de Dona Lúcia, que também é seu pai além do próprio pai dela, o Joãozinho, foi quem achou o referente da lagoa encantada ensinado por encantado corporificado no corpo do João Cosmo. Isso após a retirada de seis encantamentos pelo trabalho desse antigo pajé. Mesmo assim, a lagoa não foi desencantada, a água não brotou no meio da Mata do Amargoso e os encantamentos retornaram. A consequência disso é compreendida, na perspectiva tremembé, como uma proteção ao grupo. Caso a lagoa emergisse, as pessoas tremembé poderiam reviver o mesmo que aconteceu na Lagoa dos Negros, serem expulsos por fazendeiros.

Essa é a geração dos antigos, anterior às obras do DNOCS. A presença masculina na busca à lagoa encantada não responde à ideia de divisão do trabalho por gênero, ou por sexo. Isso porque a geração atual do trabalho é predominante constituída por mulheres. Tanto mulheres quanto homens estão passíveis de se comunicar com os encantados. Tanto o corpo de mulher como o de homem pode ser preparado para corporificar o encantado ou para entrar em comunicação com a dimensão cósmica no ambiente.

A frustração dos referidos parentes gerativos de dona Lúcia se deu em contexto de escassez de água. O encanto da água, mesmo com o apelo da sede, rendeu-se à solidariedade parental. A sede não poderia ser saciada por uma pessoa sozinha, porém, o desencantamento seria concluído somente por uma pessoa. Além disso, o grupo de homens que foi à caça da lagoa encantada eram caçadores, cuja experiência de predação serviu à busca cósmica.

A narrativa se refere a um tempo geracional anterior ao que pude experienciar. No entanto, a rotina do trabalho de cura permanece acontecendo à noite, enquanto atividades produtivas, domésticas e escolares são realizadas diuturnamente, salvo festas e reuniões extraordinárias. Porém, a agência dos encantados pode se dar tanto de dia como de noite. No entanto, caso haja alguém sob influência de espíritos durante o dia, as mulheres curadoras providenciam a suspensão das forças espirituais e efetuam a cura somente à noite no processo ritual comandado pelos encantados. Quando essa situação se repete à noite, a pessoa pajé atende, mesmo que seja de madrugada. Nesse sentido, a relacionalidade entre humanos e não humanos (espíritos), no contexto tremembé, se dá a qualquer momento do dia, ou da noite. Por outro lado, o tempo do trabalho pode durar dias, até mesmo semanas.

A orientação dos encantados se refere também a estratégia política do grupo em relação a luta pela demarcação de terra. A De Jesus, filha da liderança falecida Antônio Félix, sobrinha de Dona Lúcia, me contou que o seu cunhado José Maria viu um servidor da FUNAI dentro do posto do DNOCS, na época em que se dava o reconhecimento da comunidade de Queimadas como índios tremembéén. O senhor Antônio Félix foi a liderança principal na interlocução com autoridades de diferentes órgãos do Estado, tais como o DNOCS e a FUNAI. Ao ouvir o relato do genro, ele pediu ao primo Zé Tonheza para consultar os encantados. A seguir, destaco trecho da fala de De Jesus sobre a intervenção cósmica na relação política entre os Tremembé de Queimadas e o Estado.

Então, a gente entrou em luta, entrou em mesa de Umbanda, começou a trabalhar e aí o Sibamba foi e descobriu que o doutor [servidor da FUNAI] estava traindo nós. Aí, desse dia pra cá a gente não quis mais o doutor aqui. Aí, depois que o Nemésio entrou aqui com nós, graças a Deus, graças a Deus, que depois que o Nemésio entrou em luta com nós foi que a nossa terra foi à frente. A nossa terra foi à frente. (De Jesus, 2015).

\footnotetext{
${ }^{23}$ Em detrimento do uso dos termos etnogênese, emergência étnica ou sociogênese e da mobilização da semântica que carregam, opto por me referir à narrativa da agência dos encantados. Outros estudos já bem exploraram esse aspecto do fato étnico em tela, Cf. nota 3.
} 
Durante o meu campo, não vi a De Jesus nos trabalhos de cura. Privilegio o termo trabalho utilizado pelas mulheres curadoras com quem convivi. Entretanto, os termos luta e mesa de Umbanda revelam outras categorias de representação individual da relação entre pessoas tremembé e os encantados. Os referidos termos dizem da experiência espiritual individual que está na pessoa tremembé da geração da De Jesus, da Marluce, da Regina. No entanto, não representam a prática xamânica do trabalho de cura, a qual trato no próximo tópico.

A consulta ao encantado Sibamba, que é a entidade principal nesse trabalho, ao revelar a traição do servidor da FUNAI demonstra que o cosmo não se separa do político, como não se separam natureza e cultura. E isso se revela quando a fonte de existência das pessoas tremembé esteve ameaçada por quem tem a obrigação constitucional de protegê-la.

A natureza do direito territorial indígena é cosmopolítica, se refere a ontologia relacional entre pessoas humanas e não humanas e entre essas e o ambiente onde se perpetuam. A dinâmica dada no trabalho de cura sugere um xamanismo tremembé, o que exemplifica a natureza cosmopolítica do direito territorial indígena, no contexto nordestino.

\section{Trabalho de cura}

Numa manhã, a conversa com dona Lúcia na cozinha de sua casa me ensinou que Deus - Jesus do catolicismo - e os encantados estão juntos. Ela me explicou que a cura só acontece se houver fé dos enfermos em quem a promove, a pajé e os encantados. E que a fé em Deus é compatível com a fé no salão.

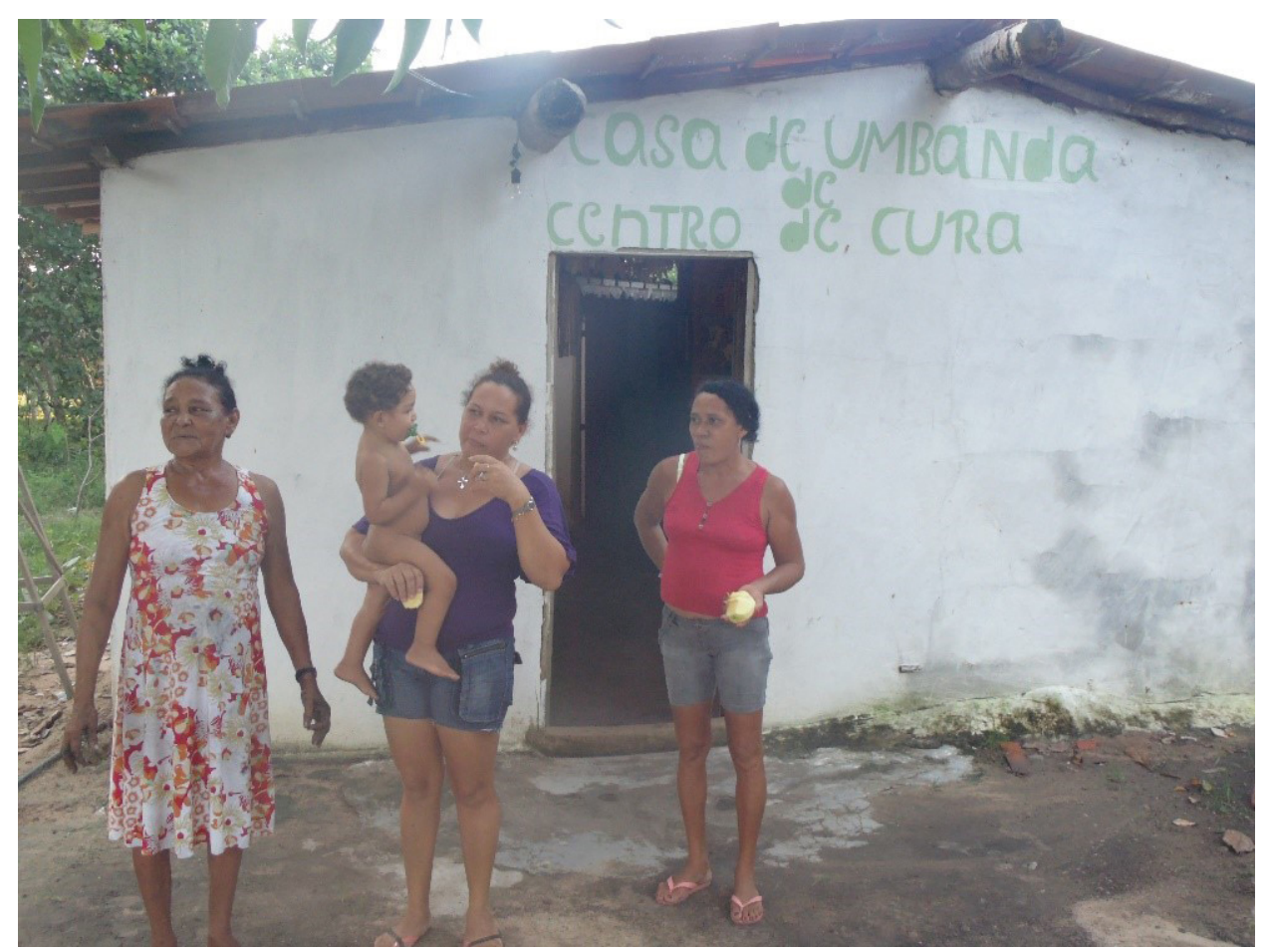

Figura 2 - A Casa de Umbanda de Centro de Cura é o salão. Da esquerda para direita: dona Lúcia, Vera (filha) com Robson (neto) e Marluce (filha), a pajé. Foto: arquivo pessoal, Julho de 2014.

Esta casa foi erguida no terreiro de dona Lúcia e é feita de alvenaria. Ela foi desfeita no mesmo período da mudança de Marluce para Telhas, em 2018²4. Outro salão foi erguido em Telhas, na TI Tremembé do Córrego do João Pereira, e lembra bastante o antigo. Ele é também de alvenaria, tem uma sala extensa, cujo centro é demarcado por uma coluna feita de tijolos na qual reside um dos apoios espirituais do traba- 
lho de cura, o mourão. Esse nome é dado também à madeira de sustentação de cercas, telhado ou coberta de casas e barracos. No salão, a função social mourão se refere a sustentar as forças espirituais necessárias ao trabalho. Isso se dá a medida que ele é contornado por uma fila de pessoas dançando e cantando as doutrinas, as canções rituais, liderada pela pajé ou por alguém que a auxilia.

Tanto as pessoas no ritual contornam o mourão para gerar força às correntes, como o mesmo se alimenta delas. A corrente de uma pessoa é a capacidade dela em corporificar e se comunicar com os encantados. Tal competência é desenvolvida no corpo e na mente de humanos. No caso do mourão, vários corpos e mentes, desenvolvidos para a comunicação cósmica ou não, formam uma corrente humana performática (que canta e dança canções rituais) capaz de gerar força para o decorrer do trabalho. As primeira horas do trabalho são vividas com bastante entusiasmo, ainda mais em noite de festa de caboclo, na qual se festeja algum encantado em especial.

Ainda no salão, há um banheiro e um quarto reservado para atendimento privado, em que o corpo da pajé modificado pela corporificação do encantado se torna o canal de comunicação entre a pessoa enferma e o encantado. Na linguagem do trabalho, o encantado é nomeado como guia, mensageiro ou caboclo. As variações do nome encantado, encanto ou encante, tanto se referem aos espíritos como a força espiritual de cura. No momento da consulta ao conhecimento cósmico, quem busca o salão, pessoa tremembé ou não, é examinado e diagnosticado por um mensageiro. Esse último encaminha o caso para um guia cujas força e conhecimento sejam capazes de curar o corpo ou a mente do enfermo, a depender do tipo de adoecimento. O guia é responsável por uma corrente, cuja força corresponde a um conjunto de encantados. Doze para cada pessoa médium. A pessoa pajé acessa quaisquer uma delas.

Geralmente, é a Pomba Gira o mensageiro que faz uso do quartinho no salão. No lado oposto à porta, única entrada e saída, fica a mesa com as estatuetas dos encantados, os vultos. Na parede adjunta dela está imagem do sagrado coração de Jesus, uma de nossa senhora, algumas fotos de trabalhos e o chapéu do falecido Zé Tonheza, irmão de dona Lúcia.

O chapéu do antigo pajé foi transformado num elemento da mesa do "salão" pela sobrinha Marluce após o encantamento dele. Eu vi ele sendo posto na pajé num final de sessão em que ela não conseguia despertar do transe. O corpo já não estava mais sob corporificação de encantados, mas a mente parecia ter perdido o caminho de volta. O retorno da alma da Marluce foi realizado por dona Lúcia, auxiliar de mesa ou ponta de mesa ao lado da sobrinha Regina. Ela pôs o chapéu do finado sobre a cabeça da pajé, denominada como coroa na linguagem ritual, e foi chamando a filha de volta cantando doutrinas para despertá-la do transe.

Somos três princesas juntas para abrir essa matéria. Vamos espertar essa árvore com a força de Nazaré; Princesa, linda princesa, filha de um rei Tamaruá (rei dos índios). Chamai a princesa para a mesa para a tua árvore despertar; Princesa do pensamento do lado do palmeiral. Tu és princesa do trono de luz do lado dos palmeirais. O teu pai era espanhol, tua mãe Oxalá. Tu és a princesa do trono de luz do lado dos palmeirais. (Doutrinas 2014).

Em pouco tempo, Marluce recuperou a consciência e a mesa foi fechada. Nas doutrinas o uso dos termos matéria, árvore, cavalo e cadáver se referem ao corpo corporificado, que é usado pelo encantado. Eles indicam o corpo da pajé como suporte para a agência dos encantados como também que no período da corporificação do encantado não existe o vínculo entre a alma da pajé e seu corpo. Ela viaja pelo mundo cósmico e doa seu corpo para os encantados exercer a comunicação com os vivos. Essa é a evidência de que o trabalho de cura tremembé pode ser pensado como um xamanismo (CUNHA 1998; CASTRO, 2002).

${ }^{24}$ Em 2017, estive em Queimadas como parte da equipe do Projeto Museu Indígena Tremembé, oportunidade em que soube da vontade da Marluce em se mudar de Queimadas para a Terra Indígena vizinha, o que aconteceu no início de 2018. 
Passo a descrever a estrutura ritual do trabalho que acontece no salão. Pude acompanhar um que aconteceu numa casa de uma pessoa tremembé na aldeia de Telhas e soube que haviam trabalhos feitos nas matas, os quais não pude acompanhar.

A Pajé Marluce, a sua mãe e a ponta de mesa Regina, juntamente com outras pessoas médiuns, todas com vestes específicas para trabalhar, blusas de manga comprida, saia comprida e a guia - um lenço grande de pescoço -, se posicionam de frente para a mesa que tem os vultos. Nessa posição, estão de costas para o público, o qual é constituído fundamentalmente por parentes consanguíneos. Rezam um pai nosso, pedem benção aos parentes presentes. Um instante de silêncio. Marluce, ou outra pessoa auxiliar que esteja em transe, dá passadas fortes para trás de modo a causar estranhamento. Ao cessar os passos, o corpo da pajé fica girando no próprio eixo em rotação lenta. A transição entre a mente da pajé e a do encantado no corpo dela finaliza quando o espírito fala: "E louvado seja Deus, para sempre seja Deus louvado, salve!" e as pessoas presentes respondem: “salve!” E ele continua dizendo "salve a minha chegada. E quem é grande?” E o público responde: “é Deus!". O encantado: “E mais do que Deus?" e a resposta é: "ninguém poderá". E é finaliza a saudação dando graças a Deus.

A partir de então o encantado prossegue a abertura da mesa. A doutrina é cantada pelo espírito que a possui. A canção apresenta o espírito e diz o que ele faz. Essa é uma forma de saber quem está corporificado. A outra é conhecer as etapas do trabalho. Quem abre a mesa é um conjunto de encantados responsável por isso. Daí, são sempre os mesmos, como é o caso do Passarinho Verde, cuja doutrina destaco a seguir.

Passarinho verde, verde azulão. Passarinho verde, verde azulão. Eu venho abrindo mesa, Foi meu pai quem me mandou. Passarinho verde, verde pena de aurora. Passarinho verde, verde pena de aurora. Eu venho abrindo mesa, com o ele banda aurora. Passarinho verde, verde pena de aurora. Eu venho abrindo mesa, com o meu rico tesouro.

No fim da canção, o encantado fala mais uma vez: "E aberta seja a mesa em nome de Deus, e mais do que Deus ninguém pode, ninguém pode mais do que Deus". As pessoas no salão respondem: "assim seja!" Para descorporificar, o encantado pede licença a pessoa que exerce a função ritual como ponta de mesa, que a concede. Em seguida, outro encantado corporifica e fala: "E louvado seja Deus, para sempre seja Deus louvado, salve!”. E a resposta é dita: salve. E assim, vai se dando a reciprocidade humana e não humana inerente à corporificação/descorporificação dos encantados no trabalho. Funciona como um bombeamento da força espiritual no salão. Como o Passarinho Verde, outros encantados vão declarando seus nomes, como o que fazem. Ao mudar o nome e a função, muda-se o rito.

A seguir destaco a doutrina do Capitão de Ronda, do grupo de encantados denominado como rondantes pelas chefes do trabalho em função da proteção realizada no salão contra os contrários, espíritos trevosos: "Ah, eu sou capitão da ronda eu cerco a ronda, se Deus quiser! Eu sou um militar. Eu boto os rondantes na rua para os contrários aqui nunca entrar" (CAPITÃO de RONDA, 2014).

Na corrente dos rondantes é que se inicia a fila para contornar o mourão. Todas as pessoas nela dançam ao mesmo tempo em que cantam a doutrina do encantado. Após os rondantes, passam as correntes das matas e a da jurema. Nessa última, se dá o passe de ronda, o qual consiste em o encantado corporificado no corpo da pajé pegar a mão de outrem e girar de modo a conduzir o outro corpo a fazer meio giro e, algumas vezes, o giro completo. Nesse momento, há pessoas que iniciam o transe, o processo de corporificação. Neste caso um lenço de pescoço, na cor de algum dos caboclos, a guia, e/ou uma saia, no caso do corpo de mulheres, são vestidos na pessoa em transe. As mulheres e homens usam blusas com mangas compridas, calças para o sexo masculino e saias compridas para o sexo feminino.

A seguir destaco duas doutrinas, a primeira é da corrente das matas e a segunda da corrente da jurema. 
E lá nas matas eu me perdi, eu me perdi. E lá nas matas de Codor (MA) eu me achei, eu me achei. Aonde foi que eu perdi esse colar que não achei. Lá na mesa de umbanda que encontrei; Ô juremeiro, ô juremal, a folha caiu serena, oi jurema vamos te limpar. Deus te salve, ô casa santa! Deus te salve oxalá! Onde mora o cálice bento e a hóstia consagrada, oi jurema! Ô juremeiro, ô juremal, a folha caiu serena, oi jurema, vamos te limpar. (Raimundão da Jurema 2014)

As consultas acontecem sempre com três mensageiros: o Sibamba, que é denominado pelas chefes como o rei das correntes, a Pomba Gira e o Negro Gérson. Eles são responsáveis pelo diagnóstico da enfermidade ligada ao corpo ou à mente da pessoa enferma. Em seguida, encaminham para um guia de uma corrente específica. O caso é avaliado e orientado pelo respectivo encantado especialista. A pessoa na função de ponta de mesa é responsável por traduzir a linguagem usada pelos encantados. A depender de cada caso - bruxaria, contrário, espinhela caída, vícios, dramas emocionais e materiais, estratégias de luta política - o caso pode ser resolvido na mesma sessão ou pode requerer algumas outras. O trabalho é pago no caso de não indígenas, o que é denominado como bandeira na linguagem ritual. Para os parentes não tem bandeira, mas favores e agrados são sempre feitos para os encantados e/ou para a pajé.

A convivência com Marluce possibilitou conversas com os parentes do seu núcleo doméstico e da família extensa vinculados ao antigo salão de Queimadas. A pajé indicou a prima Regina para eu conversar sobre o trabalho de cura em função da posição dela como ponta de mesa, na época. A Regina foi, durante minhas visitas à Queimadas, a tradutora da linguagem dos encantados para as pessoas que iam ao salão. Por isso, tivemos longas tardes de conversa sentados em cadeiras de plástico à sombra da sua casa de alvenaria ou, outras vezes, de uma árvore do seu terreiro. No círculo das cadeiras sempre estavam o marido Pedim, o irmão José Arteiro, a filha mais velha, algumas primas e duas irmãs, Jessina e Nessi.

Numa dessas tardes, Regina me disse que os contrários podem ser enviados no corpo de insetos para próximo de pessoas. Pode ir em sapo, besouro, cobra, escorpião, piolho de cobra e etc. No salão, tanto a Regina como outras mulheres que assistiam os trabalhos se referiam, frequentemente, aos contrários como insetos e num tom de desprezo. Similar ao egum no candomblé, o contrário no trabalho de cura é um espírito cuja entrada é interditada, neste caso, pelos rondantes. No entanto, no salão é possível que ele entre se estiver junto do corpo de uma pessoa.

Nesse mundo tremembé ninguém está imune aos insetos. Certa noite, Marluce me disse que não trabalharia por estar doente. No salão, a Vera, irmã da pajé, abriu a mesa e corporificou um mensageiro, o Negro Gérson, a quem Marluce explicou que teve um sonho no qual um sapo amarelo passava por debaixo dela. E, desde então, sentia dor de dente, febre e não se sentia saciada quando se alimentava. O mensageiro recomendou algumas amarrações, ou seja, Marluce estava com alguns "contrários", os quais causaram os sintomas relatados por ela. Os contrários foram amarrados e a Marluce curada.

A amarração é um rito específico para retirar o contrário do corpo da pessoa que possui e é adoecida. Amarrar um contrário consiste na agência de um corpo, da pajé ou de médium auxiliar, corporificado por encantado denominado, na linguagem do salão, como vaqueiro. Então, o vaqueiro une a parte superior de sua cabeça com a da cabeça enferma. Alguns corpos masculinos de expectadores se posicionam próximo a pessoa que manifesta os sintomas do contrário. Geralmente, o contrário corporifica no corpo de seu portador quando alguma das doutrinas de vaqueiros começa a ser cantada. A corporificação do contrário é imediata, extremamente agressiva, marcada por gritos, murros e chutes. Por isso, necessita ser contido e é retirado do corpo enfermo e amarrado no mundo cósmico e jogado no fundo do mar. Após a amarração a pessoa que estava com contrário apresenta melhora gradativa.

A seguir, destaco quatro doutrinas de vaqueiros cantadas frequentemente nos ritos de amarração. 
Eu sou o vaqueiro Pedro venho de Minas Gerais. Eu vou levar esse turino, eu dou no tronco do mourão. Montado em meu cavalo, manga de gibão metido. Eu vou levar esse turino. Eu dou no tronco do mourão; Que coração tão duro, pedaço de carne morta. Tu bota a tamanca no boi, ô seu Légua, para esse boi não vencer; Sarabatão ele vem voando. Ele vem do alto mar. Sarabatão, ele é rei, é rei. Espírito mau eu vou trancar no mar; Ai, preso e amarrado e ele já saiu. Entregue a Princesa Iolinda, trancado no fundo do mar. (Vaqueiros 2014).

Nota-se que o mourão é citado na doutrina como um tronco, remetendo à madeira, o que é um referente do universo do vaqueiro. No entanto, a conjunção cósmica entre vaqueiro e encantados transfere a força do mourão madeira de cerca para a coluna de alvenaria do salão. Com essa última o contrário é dominado, juntamente com o encantado corporificado. Há uma transmaterialidade na qual se dá o fluxo de energia espiritual e humana?

Eu vivi a agência de um contrário. Aconteceu no momento em que a corrente dos vaqueiros foi convocada, num trabalho em que foi feita uma amarração com uma pessoa tremembé de Telhas. Eu senti esfriamento do corpo, começando pelos meus braços, falta de fôlego, sensação de ambiente abafado e náuseas, durante a atuação da corrente de vaqueiros. Tudo passou somente no dia seguinte. Em conversa com Regina me dei conta de que esses sintomas se referem a presença de contrário junto do meu corpo. Porém, não foi necessária uma amarração para mim.

As doutrinas indicam também lugares no cosmo que correspondem às matas, à jurema (arbusto), ao Maranhão, à maresia, mar, fundo do mar, dentre vários outros pelos quais trafegam os encantes, e a alma da pajé e dos seus médiuns auxiliares. Os contrário são espíritos de pessoas que morreram em acidentes nas rodovias, segundo a experiência das chefes do trabalho. Eles permanecem se movendo até encontrar algum humano para acompanhar, ou ser aprisionado num inseto por algum feitiço, ou ainda até ser preso, amarrado e jogado no fundo do mar. Há poucos casos em que o contrário corporificado pede luz, ou seja, a redenção de seus mal feitos.

José Arteiro, irmão de Regina, numa das tardes de conversa, me disse que os sintomas de quando está com contrário é a vontade de correr para as matas e a raiva dentro de si. Como ele é médium desenvolvido, então esses sintomas são denominados também como sujeira nas correntes. Essa é a modalidade de adoecimento que a capacidade de transe e de incorporação do encantado está adoecida e precisa de cuidado especial orientado pelos mensageiros. De gripe à câncer, de "contrário" à bruxaria, de problemas com bebidas e drogas ao dano conjugal, os mensageiros indicam os guias que mobilizam as "correntes", dão conselhos, recomendam sessões de limpeza, de amarração e de desmanche da demanda (bruxaria), como também recomendam fazer remédios com elementos da flora e da fauna local.

Cada um dos médiuns tem uma corrente com a qual é possível corporificar doze encantados diferentes. Desses, um é o guia e dois são a mãe e o pai de coroa de cada um, inclusive da pajé. Este tipo de paternidade e maternidade espiritual não é exclusivo do trabalho, uma prática ritual ameríndia, mas é comum no candomblé e na umbanda.

Por outro lado, é uma característica fundamental no trabalho a presença de pessoas vinculadas pela consanguinidade. A agnação e a afinidade constituem a prática ritual do trabalho de cura tanto para a realização das sessões como para o desenvolvimento da capacidade de corporificar encantados. Uma pessoa que tem correntes não consegue desenvolver a capacidade de corporificar se não houver alguém do laço agnático ou afim presente nas noves sessões necessárias para tal.

A parentela espiritual é acionada nos momentos de corporificação, quando a alma da pajé ou de algum médium auxiliar abandono seu corpo para o uso dos mensageiros e guias. Na verdade, é um serviço em que se entrega a alma, literalmente. Nesse sentido, a parentela age tanto na dimensão cósmica 
como na dimensão humana e é o que possibilita a relacionalidades humana e não humana, o parentesco, tanto quanto a abertura de lugares indígenas.

\section{Considerações Finais}

As aldeias tremembés não estão, necessariamente, condicionadas a um território constituído no passado colonial. Na verdade, elas estão sendo produzidas constantemente, tanto na relação com o Estado como sem essa mediação. Antes da demarcação de Terras Indígenas precedem os lugares indígenas. Afinal, não se demarca área sem fundamentar a ocupação tradicional. Não é mais possível generalizar a relação etnicidade e território no Nordeste. As relacionalidades parentais e espirituais fundam e consolidam lugares indígenas em áreas favoráveis à subsistência, identificadas pelos saberes cósmicos e pelo conhecimento proveniente da experiência vivida, pela memória coletiva do grupo.

É possível pensar os encantados não como representação simbólica a serviço da etnicidade e do território. É uma relação ontológica fundamental na geração de pessoas tremembé, na rede parental, e na abertura de lugares encantados e aldeias. A relacionalidade humana e não humana estabelecida entre pessoas tremembé, encantados e ambiente abre a perspectica cósmica do pensamento ameríndio. $\mathrm{O}$ ambiente é vivenciado tanto pelo corpo como pelos espíritos. É possível uma lagoa ser habitada e receber nome em referência ao corpo das pessoas que a encontraram, como também é factível o seu encantamento. A interdição de acessá-la pela condição cósmica não a faz deixar de existir. Ela existe fundamentada na experiência histórica dos antigos de Queimadas, na alteração dos sentidos corporais e da mente de um corpo feito médium ou pajé.

Parte do sentido de vida Tremembé em Queimadas é constituído pelo conhecimento cósmico, seja para a cura, para a luta por território ou para encontrar água. Como havia, na época da produção dos dados, número significativo de mulheres da aldeia Telhas que auxiliavam a pajé no trabalho, então, é possível dizer que o conhecimento dos encantados gera sentido de vida nas duas Terras Indígenas localizadas no Baixo Acaraú. Essa afirmação é fortalecida com a mudança da Marluce de Queimadas para Telhas, em 2018. Gondim (2016) e Fernandes (2019) permitem estender essa compreensão para Almofala, de que a vida tremembé é significada a partir da relação com os encantados. Isso se aplica tanto para a terra do aldeamento, como para as aldeias formadas fora delas.

A parentela é fundamental para a produção de existência material e para a condicionalidade ontológica produzida entre as pessoas tremembé e os encantados. A parentela forma pessoas, produz aldeias, os lugares indígenas no ambiente, cujo pensamento humano e cósmico estão imanados. A relação com os encantados é um condicionamento ontológica. Pensar o trabalho de cura, a prática ritual da pajé Marluce no salão e fora dele como um xamanismo tremembé possibilita descrever como e com o quê pessoas tremembé estabelecem relações para poderem continuar existindo ao longo dos séculos. O xamanismo, neste contexto etnográfico, além de comunicação (Cunha 1998, Castro 2002) é uma forma de existir estando entre corpos, espíritos e ambientes (mata, praia, sertão). Corporificar um encantado é fundir o outrem cósmico no corpo do eu xamã, cuja alma viaja na dimensão espiritual.

Estabelece-se um canal de comunicação entre humanos e não humanos ao mesmo tempo em que está se produzindo parentela, pessoas e lugares indígenas, tanto em terra de aldeamento missionário como fora dela. Logo, o foco etnográfico sobre povos indígenas nordestinos deve ser em como produzem a sua existência.

A agencia dos encantados para a descoberta da Lagoa do Amargoso e encantamento da mesma, sobre a luta pela demarcação da terra indígena de Queimadas, e nos "trabalhos de cura", especialmente, na amarração de "contrários" responde a uma cosmopolítica (STENGER, 2018: 442-464) fundamentada na rede parental da líder espiritual Marluce, na atual geração de curadores tremembé no baixo Acaraú. A 
matrilinearidade a qual engendra a existência da pajé exerce influência sobre a capacidade dela em curar pessoas $^{25}$. A cognação é fundamental para o "trabalho" acontecer e para o próprio desenvolvimento da capacidade de encorporar encantados. E essa corresponde à dimensão ontológica da pessoa tremembé. Ser tremembé se refere à formação do corpo no casamento e nas vivencias parentais, no biológico, no social e moral constituídos pelo grupo do qual se é parte e naturalmente pertence, caso não haja rupturas.

Não é o território quem exerce a mediação entre a pessoa e o grupo étnico. O território é tão produzido quanto a pessoa é, ambos em meio a relacionalidade do tipo humano e não humano (com espíritos, animais, ambiente). A parentela, ao ser gerada e expandida, significa o lugar Queimadas como uma aldeia, enquanto consanguinidade. Abre-se a dimensão cósmica a partir das vivencias na mata, como também da prática tradicional do trabalho transportado de Almofala. O xamanismo como uma chave analítica permite perceber que a experiência tremembé não separa pessoas humanas de pessoas encantadas e falecidas, tão pouco se divide a dimensão humana e a dos encantes, menos ainda se distancia essas duas dimensões dos animais, das matas e da lagoa encantada. Tudo isso integra a produção de existência tremembé.

\section{Referências}

AIRES, Max Maranhão Piorsky; SILVA, Isabelle Braz Peixoto da (org.). Direitos humanos e a questão indígena no Ceará: relatório do observatório indígena biênio 2007-2008. Fortaleza, Imprensa Universitária, 2009.

BRASIL. Diário Oficial da União. Despacho nº 687, de 28 de Dezembro de 2011: Aprova conclusão do Relatório Circunstanciado de Identificação e Delimitação da Terra Indígena de Queimadas e publica resumo do mesmo. Brasília, Imprensa Nacional, 2011.

BRASIL. Diário Oficial da União. Portaria 1.318 de 7 de agosto de 2015. Número 152, Seção 1, p. 33. Brasília, Imprensa Nacional, 2015.

BRASIL. Ministério Público Federal. Nota Técnica número 02/2015. Estado Atual das Demandas Referentes à Demarcação de Terras Indígena no Estado do Ceará. Procuradoria da República no Ceará, Fortaleza, 2015.

BRISSAC, Sérgio Góes Telles; MARQUES, Marcélia. Estudo antropológico dos Tremembé da terra indígena de queimadas, município de Acaraú, Ceará. Parecer Técnico no 1/05. Ministério Público Federal, Procuradoria da República no Ceará, 2005.

CLIFFORD, James.2002. Trabalho de campo, reciprocidade e elaboração de textos etnográficos: o caso de Maurice Leenhardt; In: A experiência etnográfica: antropologia e literatura no século XX. Rio de Janeiro: Editora UFRJ, 2002. pp.227-251.

CUNHA, Manuela Carneiro da. 1978. Etnicidade: da cultura residual mais irredutível. In: CUNHA, Manuela Carneiro da. Cultura com aspas e outros ensaios. São Paulo: Cosa Naify, 2009.

FERNANDES, Janaína Ferreira. 2015. Paisagens do nordeste: Almofala dos Tremembé e os Tremembé de Almofala. Brasília-DF: Dissertação de mestrado em Antropologia Social, Universidade de Brasília.

FERNANDES, Janaína. 2019. "Encantes da terra: segredo e conhecimento entre os Tremembé de Almofala”. Ilha - Revista de Antropologia, n. 1: 38-67.

${ }^{25}$ Ver figura 1. 
GONDIM, Juliana Monteiro. 2016. Seguindo trilhas encantadas: humanos, encantados e as formas de habitar a Almofala dos Tremembé. Brasília-DF: Tese de doutorado em Antropologia Social, Universidade de Brasília.

GOW, Peter. 1997. "O parentesco como consciência humana: o caso dos Piro". Mana v. 3, n. 2: 39-65.

HERMANN, Hebert Walter; MARÉCHAL, Clémentine Ismerie. 2018. “O xamanismo Kaigang como potência descolonizadora". Horizontes Antropológicos n. 51: 339-370.

JACKSON, Michael. 2013. “The scope of existential antrhopology”. In JACKSON, Michael. Lifeworlds: Essays in Existencial Anthropology. P.3-30. Chicago: University of Chicago Press.

LIMA, Ronaldo de Queiroz. 2011. Festa do Reiso: estudo etnográfico do reisado no município de Acaraú-CE. Monografia em Ciências Sociais. Universidade Federal do Ceará, Fortaleza, 2011.

LIMA, Ronaldo De Queiroz. Os Tremembé do centro de cura, em Queimadas: a formação de um grupo social. Dissertação de mestrado em Sociologia. Universidade Federal do Ceará: Fortaleza, 2015.

LOPES, Ronaldo Santiago. 2014. A cultura de índio, seu menino, vem de longe aqui: formação histórica e territorialização dos Tremembé/CE. Dissertação de mestrado em Antropologia Social. Universidade Federal do Rio Grande do Norte, Natal, 2014.

MESSEDER, Marcos Luciano Lopes. 2012. "Etnicidade e ritual tremembé: construção da memória e lógica cultural”. Revista de Ciências Sociais n.2: 32-42.

OLIVEIRA JÚNIOR, Gérson Augusto. Torém: brincadeira dos índios velhos. São Paulo: Annablume, 1998.

PATRÍCIO, Marlinda Melo. Relatório circunstanciado de identificação e delimitação da TI Tremembé de Queimadas, Acaraú/Ceará. Brasília: Fundação Nacional do Índio, 2010.

POMPEU SOBRINHO, Thomaz. Índios Tremembé. Revista do Instituto do Ceará. Fortaleza: Editora Instituto do Ceará LTDA, 1951.pp.257-267. Disponível em: https://www.institutodoceara.org.br/revista/Rev-apresentacao/RevPorAnoHTML/1951indice.html . Acessado em 5 de outubro de 2020.

SILVA, Christhian Teófilo da. Relatório circunstanciado de identificação e delimitação da TI Tremembé Córrego do João Pereira, município de Itarema/Ceará. Brasília: Fundação Nacional do Índio, 1999.

SILVA, Isabelle Braz Peixoto da. "O relatório provincial de 1863 e a expropriação das terras indígenas". In: OLIVEIRA FILHO, João Pacheco de (organizador). A presença indígena no Nordeste: processos de territorialização, modos de reconhecimento e regimes de memória. Rio de Janeiro: Contra Capa, 2011.pp.327-346.

SILVA. Isabelle Braz Peixoto da. Vilas de índios no Ceará Grande: dinâmicas locais sob o Diretório Pombalino. São Paulo: Pontes Editores, 2005.

STENGERS, Isabelle. 2018. "A proposição cosmopolítica”. Revista do Instituto de Estudos Brasileiros n. 69: 442-464.

VALLE, Carlos Guilherme Octaviano do. "Aldeamentos indígenas no Ceará do século XIX: revendo argumentos históricos sobre desaparecimento étnico". In: PALITOT, Estevão Martins (organizador). Na mata do sabiá: contribuições sobre a presença indígena no Ceará. Fortaleza: Secult/Museu do Ceará/ Imopec, 2009.pp. 107-154. 
VALLE, Carlos Guilherme Octaviano do. 2011. “Terras, índios e caboclos em foco: o destino dos aldeamentos indígenas no Ceará (século XIX)". In: OLIVEIRA FILHO, João Pacheco de (organizador). A presença indígena no Nordeste: processos de territorialização, modos de reconhecimento e regimes de memória. Rio de Janeiro: Contra Capa, 2011.pp.447-482.

VIEIRA, José Glebson. Amigos e competidores: política faccional e feitiçaria nos Potiguara da Paraíba. Tese de doutorado em Antropologia Social. Universidade de São Paulo, São Paulo, 2010.

\author{
Recebido em 05/06/2020 \\ Aceito em 08/07/2020
}


